\title{
New Tools in HCV Diagnosis, in Light of the Enhanced Awareness and the New Drugs for Treatment: SMARTube and Stimmunology
}

\author{
Svetlana Gorodin, ${ }^{1}$ Serhat Unal, ${ }^{2}$ Youchun Wang, ${ }^{3}$ Mikhail I. Mikhaylov, ${ }^{4}$ \\ Ludmila Bigbulatova, ${ }^{5}$ and Tamar Jehuda-Cohen ${ }^{1,6}$ \\ ${ }^{1}$ SMART Biotech Ltd., Rehovot 76705, Israel \\ ${ }^{2}$ Section of Infectious Diseases, Department of Medicine, Faculty of Medicine, Hacettepe University, Ankara, Turkey \\ ${ }^{3}$ Department of Cell Biology, National Institute for Control of Pharmaceutical and Biological Products, Beijing 100050, China \\ ${ }^{4}$ Chumakov Institute Poliomyelitis and Viral Encephalitides, Russian Academy of Medical Sciences, Moscow 142782, Russia \\ ${ }^{5}$ Laboratory Department, Kogalym City Hospital, Kogalym, Russia \\ ${ }^{6}$ Technion, Biomedical Faculty, Haifa, Israel
}

Correspondence should be addressed to Tamar Jehuda-Cohen; tamar@smartube-bio.com

Received 11 October 2012; Accepted 2 December 2012

Academic Editors: E. Bogner, C. Devaux, K. Ikuta, and D. Van Baarle

Copyright (C) 2013 Svetlana Gorodin et al. This is an open access article distributed under the Creative Commons Attribution License, which permits unrestricted use, distribution, and reproduction in any medium, provided the original work is properly cited.

With improved HCV therapy, challenges regarding HCV diagnosis, such as seronegative window period, false positive readings, and differentiation between recent, chronic, and resolved infections, are of increasing importance. To address these challenges an innovative device-SMARTube HIV \& HCV - was used. Blood samples were tested for anti-HCV antibodies before and after incubation in the SMARTube, which promotes the in vitro stimulation of in vivo HCV primed lymphocytes, thus enhancing levels of anti-HCV antibodies. Comparing antibody levels, in concordant samples before and after SMARTube, yielded the Stimulation Index (SI). Among 5888 fresh blood samples, from various populations and regions worldwide, 641 were seropositive using plasma, while SMARTube processing (yielding enriched plasma, termed SMARTplasma) enabled diagnosis of 10 additional carriers in highrisk cohorts, that is, earlier detection. Using SMARTplasma eliminated all false positive results, using the current assays. In addition we show that SI calculation may serve as an important tool for differentiating between those who recently seroconverted, carriers of long-term infection, and those who have cleared the virus. SMARTube and the SI could lead to better, more informative diagnosis of HCV infections and play an important role in changing the way we treat both the infected individuals and the epidemic as a whole.

\section{Introduction}

1.1. HCV Epidemiological Overview. The hepatitis $\mathrm{C}$ virus (HCV) represents a global problem for public health systems worldwide due to its high prevalence, high rates of transfer, and severe health complications. Moreover, HCV is often missed during the initial stages of the disease due to lack of symptoms in the infected person $[1,2]$. Later, most of these symptomless, yet $\mathrm{HCV}$-infected, individuals will progress to chronic HCV infection [1,3] and have a significant increased-risk of liver cirrhosis, hepatocellular carcinoma, and liver transplantation $[3,4]$.
Hepatitis $\mathrm{C}$ is a global epidemic, and according to the World Health Organization (WHO), about 130-170 million people are chronically infected with hepatitis $\mathrm{C}$ virus worldwide [2]. Recent investigations have suggested that at least 5.2 million persons in USA [5] and over 5 million persons in the Russian Federation [6] are living with $\mathrm{HCV}$ today. It is estimated that each year 3-4 million people are newly infected with $\mathrm{HCV}$, and more than 350,000 people die from hepatitis $\mathrm{C}$ related liver diseases annually [2]. HCV prevalence in the general population varies from $0,5 \%$ in Northern Europe, up to 2\% in Mediterranean countries, 3\% 
in China, and above $4.8 \%$ in Pakistan, and reaches more than $20 \%$ in Egypt [2, 7-10].

Incidence rates across the world vary and are difficult to calculate; however, information about the routes of $\mathrm{HCV}$ transmission $[2,11]$ and the populations with high risk for HCV infection [12] is important for estimating it. Recipients of blood, blood products, or organs [13-19], and injecting drug users (even those who injected drugs once many years ago) [20-22], are the highest risk groups in many countries. Patients on long-term hemodialysis also have a higher rate of $\mathrm{HCV}$ infection [23] than the general population. Prevalence of HCV infection among patients on hemodialysis therapy increases with the duration of hemodialysis treatment, and it varies between 5-70\% [24-29]. It is also important to note the remarkably high occupational risk for health-care workers (HCWs). Hepatitis C virus is one of the most common bloodborne pathogens transmitted from patients to HCWs [3034]. It is also transmitted tattooing, body piercing, and other forms of skin penetration.

According to CDC data [35], there are indications that sexual transmission of hepatitis $C$ virus is associated with high-risk sexual activity and other STD's $[36,37]$. Of note is also the fact that $\mathrm{HCV}$ viral loads are significantly elevated among individuals coinfected with HIV [38-40]. This also affects the rate of mother-to-child transmission which is estimated at 5\%, while coinfection with HIV increases the risk to $19.4 \%$ [41].

In the last two years the HCV epidemic and its association with HIV have finally reached the international "spot light." In order to increase the awareness and understanding of viral hepatitis and the diseases that it causes, the WHO has marked the 28th of July 2011 as the first official World Hepatitis Day [2]. CDC joined the WHO initiative, calling for a renewed commitment against a largely silent but persistent epidemic [42-44], hoping to provide an opportunity for coordinating a global worldwide response to the hepatitis epidemic. International awareness can help focus different efforts and resources on multifactor actions such as prevention, screening, and control of viral hepatitis and its related diseases.

1.2. Challenges in HCV Management. In countries around the world (e.g., Canada, USA, Brazil, France, China, and Turkey), attention is focused on development and implementation of different approaches for management of hepatitis $C$ virus (HCV) infection in order to diagnose the infection, guide treatment decisions, and assess the virological response to antiviral therapy $[18-20,45,46]$.

New oral antiviral therapy for HCV [47-50], with lower toxicity and a shorter duration of treatment [51, 52], ushers in a new era. The advances in HCV treatment to make the arguments for early treatment much stronger, together with better tools for HCV diagnosis, could significantly improve treatment decisions [53].

There are two main categories of tests for HCV infection: tests for antibody and tests for viral antigens or viral RNA [54-56]. Detection of anti-HCV antibodies in plasma or serum is based on identification of $\operatorname{IgG}$ antibodies against several HCV antigens [57]. There are currently no assays for anti-HCV IgM antibodies. Thus on one hand, there are new effective drugs for early management of HCV infection while on the other hand, a diagnosis of early infection is often missed as the IgG anti-HCV antibodies are not detectable till several months after infection [48, 58-62]. Tools for differentiating between cleared and chronic infection are also needed [2].

The multiple challenges in HCV diagnosis can be divided into the following three groups: false negative test results during a long seronegative window period; significant and varying levels of false positive test results; differentiation between current/chronic infection and cleared/resolved infection. In addition, differentiation between recent and nonrecent infection would benefit both the patient (choice of treatment regime) and society (identification of sources of new infections).

\subsubsection{Negative Test Results during a Long Seronegative Window} Period. Unlike most viral infections, antibodies against HCV do not appear within 5-10 days of the exposure to the infection. There is a seronegative window period (WP) of several months [58-65]. Which means that most of the recently infected individuals will test HCV seronegative during the WP and thus will be missed.

The length of the WP depends, among other factors, on the general immune state of the patient [45] and may last as long as 6 to 12 months in immunocompromised or immunosuppressed patients $[56,66]$. Immunosuppressive condition has been associated with HIV or HBV coinfection, organ transplants, and chronic hemodialysis $[1,56,64,66]$. For example, there is a decrease of adaptive HCV-specific immune response in coinfection with HIV, [67]. Humoral immune responses to $\mathrm{HCV}$ during the acute phase were inhibited in the presence of active HBV replication, leading to poor antibody responses to HCV [68].

Antigen and nucleic acid amplification tests (NATs) allow for direct viral detection and have been shown to reduce the WP for detection of HCV infection by up to 60 days [6971 . Due to high cost of NAT methods pooled samples (1096 per pool) $[60,65,72,73]$ are used for donor screening in many of the developed countries $[59,72,74-76]$. Due to the pooling, the samples are diluted, leading to cases where preseroconversion donations were negative by both $\mathrm{Ab}$ testing and pooled PCR $[72,73,75,77,78]$.

Kretzschmar et al. described a case of transfusionacquired HCV infection from an extremely low-titer donation [77]. HCV transmission can be caused by donations that escape NAT detection even when tested in an individual donation. Several cases of hepatitis $\mathrm{C}$ transmission from $\mathrm{HCV}$ seronegative tissue donors have been recently reported in the USA. Four transplant recipients in Chicago have contracted $\mathrm{HIV}$ and hepatitis $\mathrm{C}$ virus from an organ donor who tested negative for both viruses [79]. According to US healthcare officials, that happened "because the donor was infected too recently for commonly used blood tests to detect the infection." The United Network for Organ Sharing (UNOS) notified the US CDC of two patients who tested positive for $\mathrm{HCV}$ infection approximately 6 months after receiving kidney transplants from a seronegative, deceased donor [80]. This raised questions concerning current serologic testing 
policies and prompted a study to estimate the WP between infection and actual diagnosis by available laboratory testing algorithm [81].

In light of the above, finding a solution to the long WP remains an important goal in transfusion, transplantation, and diagnostic settings. Based on the fact that the long window period between HCV infection and detectable seroconversion is not due to lack of antigenic stimuli, it could be concluded that the WP is long, due to, at least in part, to specificimmune suppression [82]. Development of innovative technological solution which would overcome this immune suppression may lead to much needed progress in the field of earlier and better diagnosis of $\mathrm{HCV}$ infection.

1.2.2. Significant Level of False Positive Test Results. Current $\mathrm{HCV}$ diagnostic assays have high rates of false positives [83-85]. To add to the complexity of deriving true HCV prevalence information from testing programs and surveys, the false positive rates vary from population to population and from country to country [86-89]. This is a major concern as it means, on the epidemiological level, that we overestimate prevalence, in varying, and unknown, degrees, in different populations around the world. From another point of view, the low specificity of anti-HCV antibody assays $[85,88,90]$ affects the blood supply, as it causes a loss of noninfected blood units, and the temporary deferral of the donor leads to additional potential loss of blood donations.

1.2.3. Problems Differentiating between Early/Recent Infection and Long-Term/Chronic Infection and the Need for Better Markers for Cleared or Resolved Infection. As high as 25\% of HCV infected persons spontaneously clear the virus $[1,2$, 91-95]. Current serology tools cannot differentiate between cleared/resolved infections and chronic/current ones. This is due to the fact that those who resolve the infection remain anti-HCV positive for many years [96, 97]. Clearance of hepatitis $\mathrm{C}$ depends on many factors such as genetic variants of host's genes [98], virus genotype [99], medical treatment of disease $[100,101]$, and general status of the immune system. Resolved infections have been frequently associated with a strong HCV-specific cellular immune response $[89,102,103]$. IgG has a half-life of 21 days [104], and therefore, following the clearance of the virus, high levels of anti-HCV antibodies will remain in the blood, for years to come. Using molecular assays for the detection of viral genome, as in the case of acute HCV infection, offers only a partial solution [97]. Moreover, lack of detection of HCV viral genome in the blood is not an indication of the state of HCV infection in the target organ (liver) $[105,106]$. Thus, available assays do not provide effective tools for optimal differentiation of current and cleared HCV infection.

These issues were in the spotlight of discussion during the 2011 HCV Symposium (CDC, Atlanta, USA, 2011). In particular, Dr. John W. Ward quoted the United States Department of Health and Human Services plan for the prevention, care, and treatment of viral hepatitis and emphasized the following actions as the most important: identify persons infected with viral hepatitis early in the course of their disease; assess new laboratory tests to accurately identify persons infected with viral hepatitis; develop and implement new technologies to improve viral hepatitis surveillance; develop approaches to detect and treat acute HCV in IDUs [53].

1.3. Stimmunology and the SMARTube as a Novel Solution to the HCV Diagnostic Challenges. A novel approach for improving anti-HCV antibodies-based diagnosis, which can overcome the challenges stated above, has been developed. The approach is based on Stimmunology, a technology which leads to the stimulation of antibody production, in a whole blood sample, in vitro, even in the face of specific immune suppression. Using this technology, via the SMARTube for $\mathrm{HCV}$, enables us not only to look at the levels of HCV antibodies in the plasma, but also to measure the levels of $\mathrm{HCV}$ antibody produced in vitro, in a whole blood sample, thus measuring not only what has been produced in the past but also the current capability and potential for antibody production (or lack of) at the time of testing.

The innovative technology-Stimmunology (ST) - has been developed for the in vitro stimulation of in vivo immunesensitized (or -primed) lymphocytes, specific to HIV, overcoming specific immune suppression and enhancing the production of HIV antibodies in culture. This was achieved by a proprietary formulation of bioactive compounds, in a tissue culture step. Using the Stimmunology process, the $\mathrm{HCV}$-primed B cells, which are not yet producing anti-HCV antibodies in vivo, produce them in vitro, thus enabling the detection of the hepatitis $\mathrm{C}$ earlier in the course of the infection. This technology was initially developed for overcoming the WP in HIV (and SIV) infection. Using a monkey model of AIDS (SIV), it has been shown, in experimental infections, that the specific antibodies can be detected in the culture supernatant within days of infection, weeks and even months prior to seroconversion in vivo $[107,108]$. Similar findings for overcoming the HIV seronegative window period were reported in studies where Stimmunology was used as a blood sample processing step, inside the SMARTube, prior to routine lab testing for HIV antibodies [109-113].

Following the development of the SMARTube for HIV, a SMARTube for HCV was developed, and then the two formulations were combined to create a stimulation formula for both HIV and HCV in one SMARTube. Following its development the SMARTube was tested, as a blood pretreatment step prior to HCV antibody testing, in various cohorts and populations across different geographical regions worldwide. The aim of the studies was the evaluation of SMARTube-based detection of HCV-infected individuals, as an improved tool for overcoming the multiple challenges of HCV diagnosis.

\section{Materials and Methods}

In order to evaluate the efficacy of the SMARTube as a tool for solving some of the problems of HCV diagnosis, clinical trials were conducted in several populations with high or low risk for $\mathrm{HCV}$, from geographical regions with different prevalence of HCV [116]. A total of almost six thousand blood samples, both with and without SMARTube pretreatment, were tested for anti-HCV antibodies. The fresh blood samples 
TAble 1: Prevalence of HCV antibody positive individuals detected using regular plasma.

\begin{tabular}{|c|c|c|c|c|c|}
\hline $\begin{array}{l}\text { Risk of HCV } \\
\text { transmission }\end{array}$ & Population/cohort studied & Country & $\begin{array}{c}\text { Total samples } \\
\text { tested }\end{array}$ & $\begin{array}{l}\text { Serology } \\
\text { positive }^{* *}\end{array}$ & $\begin{array}{l}\text { HCV prevalence } \\
\text { rate }\end{array}$ \\
\hline \multirow{3}{*}{$\begin{array}{l}\text { Suspected HCV } \\
\text { infection }\end{array}$} & $\begin{array}{l}\text { Timisoara hospital patients, with suspected HCV } \\
\text { infection [114] }\end{array}$ & Romania & 143 & 27 & $18.90 \%$ \\
\hline & $\begin{array}{l}\text { Testing of individuals, } 1-3 \text { weeks after reported } \\
\text { suspected exposure to HCV }\end{array}$ & Romania & 40 & 7 & $17.5 \%$ \\
\hline & $\begin{array}{l}\text { Hacettepe University Hospital patients with } \\
\text { suspected HCV infection }\end{array}$ & Turkey & 500 & 22 & $4.4 \%$ \\
\hline \multirow{4}{*}{$\begin{array}{l}\text { Populations with high } \\
\text { risk of HCV } \\
\text { transmission }\end{array}$} & $\begin{array}{l}\text { Seronegative individuals with very high risk of } \mathrm{HCV} \\
\text { transmission }\end{array}$ & Israel & 67 & 4 & $5.97 \%$ \\
\hline & Intravenous drug users, (Sichuan Province) & China & 653 & 389 & $59.57 \%$ \\
\hline & $\begin{array}{l}\text { Discordant (HIV) couples-patients of Moscow } \\
\text { AIDS Center [109] }{ }^{*}\end{array}$ & Russia & 24 & 6 & $25 \%$ \\
\hline & Patients of Budapest AIDS center $[115]^{*}$ & Hungary & 206 & 25 & $12.13 \%$ \\
\hline \multirow{4}{*}{$\begin{array}{l}\text { General populations } \\
\text { with low risk behavior } \\
\text { and unknown HCV } \\
\text { prevalence }\end{array}$} & $\begin{array}{l}\text { Ethiopian immigrants in Israel, unknown prevalence } \\
\text { of HCV in population }\end{array}$ & Israel & 238 & 3 & $1.26 \%$ \\
\hline & $\begin{array}{l}\text { Unknown prevalence of HCV in population (Hebei } \\
\text { Province), infection due to bad medical practices in } \\
\text { the past }\end{array}$ & China & 583 & 139 & $23.84 \%$ \\
\hline & $\begin{array}{l}\text { Kogalym hospital patients and medical staff, } \\
\text { population with mixed risk level }\end{array}$ & Russia & 330 & 7 & $2.12 \%$ \\
\hline & $\begin{array}{l}\text { Replacement blood donors in Kenyatta blood bank, } \\
\text { unknown prevalence }\end{array}$ & Kenya & 294 & 8 & $2.72 \%$ \\
\hline \multirow{4}{*}{ Low risk populations } & Healthy blood donors (Tel Aviv) & Israel & 625 & 0 & 0 \\
\hline & Healthy blood donors (Beijing) & China & 1552 & 4 & $0.26 \%$ \\
\hline & Healthy blood donors (Bucharest) & Romania & 608 & 0 & 0 \\
\hline & Healthy blood donors (Moscow) & Russia & 25 & 0 & 0 \\
\hline
\end{tabular}

* Data was presented at a local conference.

** HCV seropositives, confirmed by local algorithms.

were collected in Israel, China, Romania, Kenya, Turkey, Hungary, and Russia during research and/or routine clinical testing over a period of over ten years (1997-2010). A list of specimens for analysis and cohorts studied are presented in Table 1.

Blood samples, from listed populations, were collected into heparin containing tubes and kept at room temperature till laboratory handling within 24 hours. From each sample of heparinized whole blood, $1 \mathrm{~mL}$ was put into SMARTube HIV \& HCV [117] for the Stimmunology processing. After 3-5 days of incubation in tissue culture conditions (at $37^{\circ} \mathrm{C}$ in a $5 \% \mathrm{CO}_{2}$ humidified incubator), the supernatant, termed SMARTplasma, was collected for anti-HCV antibody testing (Figure 1). The testing of SMARTplasma was always done in parallel with the regular plasma samples, using standard serology assays and the routine diagnostic algorithm, as approved in the country of testing. Cut-off value was calculated according to manufacturer's instruction in each case separately. All initially reactive samples were confirmed by repeat testing of the same sample, on the same ELISA and/or on an additional different antibody tests. The ratio between the antibody levels in the SMARTplasma and the antibody levels in the parallel plasma (from the same blood sample), termed the Stimulation Index (SI), was calculated for each individual.
All clinical studies were conducted in conformation with the Helsinki agreements and local guidelines. The studies described involved only adults and were part of the general testing routine. Most of the samples were unlinked, and the blood samples were identified by a serial number only with no other identification details. Due to the clinical studies being cross-sectional, with most of the samples unlinked, follow-up testing was usually not possible.

\section{Results and Discussion}

3.1. HCV Prevalence in Studied Populations and Regions. A total of 5888 blood samples were tested by standard serology algorithm, and prevalence of anti-HCV antibodies in the target populations was calculated based on confirmed serology results (see Table 1). According to WHO and CDC data $[2,118]$, prevalence of $\mathrm{HCV}$ infection varies among various geographic regions. In our study, HCV prevalence varied from $5-6 \%$ in Mediterranean countries to $12-25 \%$ among patients from AIDS Centers in Eastern Europe. A rather high percentage of individuals with anti-HCV antibodies (18\%) was found among those with a suspected recent exposure to hepatitis C in Romania. The highest prevalence (59.57\%) was found in a cohort of intravenous drug users from Sichuan province, China. Regional prevalence rates in China 


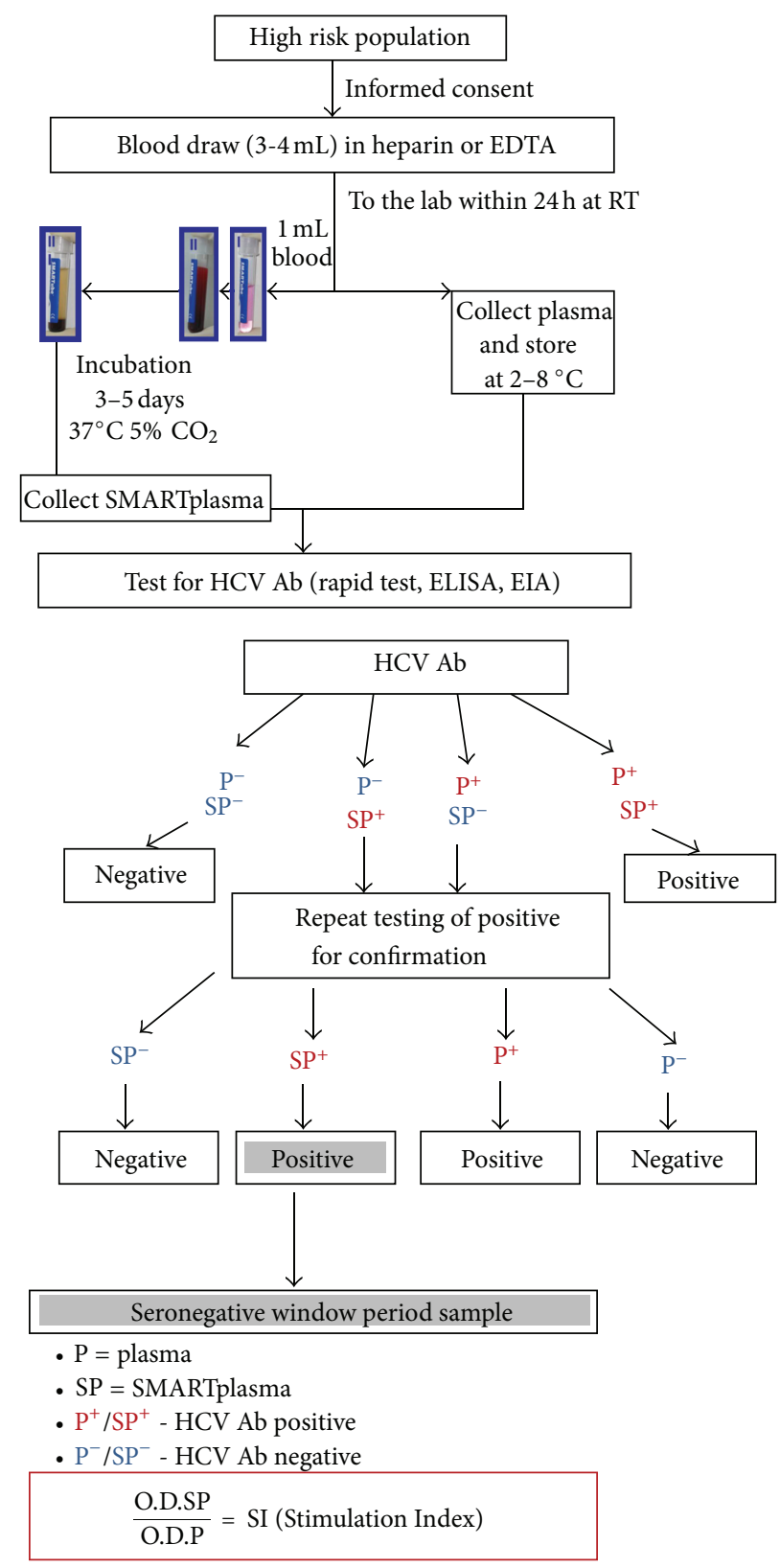

FIgURE 1: Clinical study flow chart.

were reported to range from $0 \%$ to $31.9 \%$ [118]. Most of the infections, both in China and in Eastern Europe, were attributed to transmissions during the 1980s and 1990s which were associated with transfusions of unscreened blood and injections with improperly sterilized equipment [119-124].

\subsection{SMARTube Enabling the Detection of Window Period} Samples. The blood for the Stimmunology step and the plasma were both from the same blood sample, and thus the resulting cultured supernatant, termed SMARTplasma, and the plasma samples could be compared (Table 2). Among the 5888 blood samples which were collected from various groups in different geographical regions, 641 were seropositive in routine serology testing. Seropositive samples were also positive following the SMARTube step; that is, no loss of diagnostic sensitivity was observed.

The SMARTube was used to enhance the in vivo primed lymphocytes, in a whole blood sample, to proliferate and differentiate, leading to in vitro stimulation of specific antibody synthesis. In the reported studies, the SMARTube led to the diagnosis of 10 additional positive persons, thus increasing the diagnostic sensitivity of the antibody assays used. No additional HCV positive samples were observed, using SMARTplasma, among blood donors and among the 
TABLE 2: Early HCV infections missed by current serology and detected using the SMARTube pretreatment step and SMARTplasma as the sample tested.

\begin{tabular}{|c|c|c|c|c|}
\hline Population studied & $\begin{array}{c}\text { Positive using } \\
\text { plasma }^{*}\end{array}$ & $\begin{array}{l}\text { Positive using } \\
\text { SMARTplasma }\end{array}$ & $\begin{array}{c}\text { Individuals in } \\
\text { window period }^{* *}\end{array}$ & $\begin{array}{l}\text { Rate of missed } \\
\text { infections }\end{array}$ \\
\hline Suspected HCV infection & 56 & 61 & 5 & $8.1 \%$ \\
\hline Populations with high risk of HCV transmission & 424 & 428 & 4 & $0.9 \%$ \\
\hline Regular populations with unknown HCV prevalence & 157 & 158 & 1 & $0.6 \%$ \\
\hline Healthy donors, low risk populations & 4 & 4 & 0 & $0 \%$ \\
\hline Total & 641 & 651 & 10 & \\
\hline
\end{tabular}

TABLE 3: HCV false positive rates using regular plasma versus SMARTplasma as the tested sample.

\begin{tabular}{|c|c|c|c|c|c|}
\hline Population studied & $\begin{array}{l}\text { Total samples } \\
\text { tested }\end{array}$ & $\begin{array}{l}\text { Initially reactive } \\
\text { plasma samples }\end{array}$ & $\begin{array}{c}\text { False positive } \\
\text { plasma samples* }\end{array}$ & $\begin{array}{l}\text { False positive results } \\
\text { rate in population }{ }^{* *}\end{array}$ & $\begin{array}{c}\text { False positive } \\
\text { SMARTplasma } \\
\text { samples }\end{array}$ \\
\hline Suspected HCV infection & 683 & 64 & 8 & $1.1 \%$ & 0 \\
\hline $\begin{array}{l}\text { Populations with high risk of } \mathrm{HCV} \\
\text { transmission }\end{array}$ & 950 & 431 & 7 & $0.7 \%$ & 0 \\
\hline $\begin{array}{l}\text { Regular populations with unknown } \mathrm{HCV} \\
\text { prevalence }\end{array}$ & 1445 & 167 & 10 & $0.7 \%$ & 0 \\
\hline Healthy donors, low risk populations & 2810 & 11 & 7 & $0.2 \%$ & 0 \\
\hline Total & 5888 & 673 & 32 & $0.5 \%$ & 0 \\
\hline
\end{tabular}

False positive by regular serology according to the local algorithms (e.g., negative upon repeat testing).

** Percent of false positive results among total plasma samples tested in that population.

general population, across all observed geographical regions, indicating no loss in diagnostic specificity.

Of 950 SMARTplasma, four and five window period samples were from individuals with high risk of HCV transmission and 40 from individuals who were recently exposed to $\mathrm{HCV}$, respectively. All samples which tested positive only after the SMARTube incubation were confirmed by second HCV ELISA positive test of the SMARTplasma (data not shown).

It should be noted that the level of increase in diagnostic sensitivity depends on both the length of the seronegative window period and the incidence level in each population. In the current study, the highest level of recent infections was observed among individuals who reported exposure to HCV in the last $1-3$ weeks (8.1\%). Seven of those 40 tested individuals were seropositive by regular serology, indicating nonrecent infections, and five were missed by regular serology and detected only using the SMARTube, indicating an infection which could be due to the reported exposure. Similar results were reported among individuals at high risk for HIV and in populations with a high incidence rate [125]. Such findings in the Ethiopian [110] and Kenyan [112] cohorts seem to indicate a longer window period for HIV in those African populations.

Thus, using the SMARTube overcomes the challenge of the long seronegative window period in $\mathrm{HCV}$ infection. Ability to detect infection earlier, without having to wait for the in vivo production of antibodies to reach detectable levels, could provide an opportunity for treatment by new drugs for early HCV therapy. Starting treatment at such early stages might enable, in the future, lower doses of drugs and shorter treatment duration [53].

3.3. ST as a Tool for Decreasing False Positive Rates in HCV Diagnostic. Among the 5888 blood samples tested using both plasma and SMARTplasma there were 673 initially reactive plasma samples (Table 3). Of these, 32 tested as clear negative using SMARTplasma as the sample. Repeat testing of those 32 initially reactive plasma samples showed them to be false positive readings, indicating that the SMARTplasma results were true, and that using the SMARTube reduced the false positive rate by $100 \%$. The seven patients from Kogalym Hospital in Russia, who were initially antibody positive in plasma and SMARTplasma negative, were followed for 1 year, and none of them seroconverted. Of special concern is the high rate of false positive results among the initially reactive samples in low risk populations. Among 2810 healthy blood donors from different countries, there were 11 plasma positive donors while $7(63.6 \%)$ of them were negative by SMARTplasma. These 7 were also negative upon repeat testing of the plasma, indicating that the negative results following Stimmunology pretreatment were all noninfected, bringing to zero the false positive rate.

Similar results were reported during the laboratory evaluation of SMARTube-enabled HIV detection among the replacement donors' population in Kenya. All samples which 
TABLE 4: Stimulation Index (SI) distribution among HCV infection disease stages (according to clinical laboratory results of HCV antibody testing on current assays).

\begin{tabular}{|c|c|c|c|c|}
\hline \multirow{2}{*}{ Countries } & \multicolumn{4}{|c|}{ HCV infection stages and SI distribution } \\
\hline & $\begin{array}{c}\text { Window period } \\
\text { SI }=\infty\end{array}$ & $\begin{array}{c}\text { Recent seroconversions }{ }^{* *} \\
\text { SI }>1.2\end{array}$ & $\begin{array}{c}\text { Chronic infections }^{* *} \\
0.8<\mathrm{SI}<1.2\end{array}$ & $\begin{array}{c}\text { Cleared infections } \\
\text { SI }<0.8 \\
\end{array}$ \\
\hline Russia & 0 & 0 & 13 & 0 \\
\hline Romania & 5 & 0 & 21 & 9 \\
\hline Turkey & 0 & 3 & 12 & 7 \\
\hline Kenya & 1 & 0 & 7 & 1 \\
\hline Hungary & 1 & 0 & 19 & 4 \\
\hline China & 2 & 9 & 520 & 0 \\
\hline
\end{tabular}

${ }^{*}$ HCV infections missed by regular serology, but detected using the SMARTube blood pretreatment step.

${ }^{* *}$ HCV seropositives, confirmed by local algorithms.

were plasma positive yet were SMARTplasma negative at the initial testing were found to be plasma negative upon repeat testing, that is, gave a false positive reading at the initial screening. Thus, in the diagnosis of both HCV and HIV infection, using the SMARTube, and testing the SMARTplasma, instead of plasma, has improved the specificity of the currently available antibody tests by as high as $100 \%$. This is probably due to two processes which take place during the incubation of a blood sample in the SMARTube: the SMARTube preanalytical step leads to elevation of the specific signal, by increasing of HCV- and/or HIV-specific antibodies level in the blood sample; and the incubation of the whole blood in the SMARTube decreases the relative levels of nonspecific antibody binding and possible "noise" by the dilution of the blood sample ( $1 \mathrm{~mL}$ blood $=\sim 0.5 \mathrm{~mL}$ plasma) by the SMARTube solution $(2 \mathrm{~mL})$.

It is well known that there is a negative correlation between the levels of diagnostic sensitivity and specificity. Increasing diagnostic sensitivity usually comes at the account of reduced specificity and vice versa. This is true for diagnostic kits and assays; however, the SMARTube is not a diagnostic kit. While an increase in the diagnostic sensitivity, when using SMARTplasma versus plasma, could have been accompanied by a decrease in diagnostic specificity, this is not the case. The above-reported data indicate that the Stimmunology step actually decreased (actually eliminated, in these studies) the rates of false positive readings among blood donors and low risk groups; that is, it increased the specificity of the testing kits. Since, according to blood banks' safety rules, any blood unit with a positive antibody reading must not be released for clinical use [70,74, 112], any false positive reading means a loss of a blood unit and some delay in reentry of the donor into the donor pool. In view of the ongoing shortage of donors, blood units and blood components, improving the specificity of available screening tests offers an opportunity to reduce the loss of good blood units, which has both economical and medical benefits [126].

3.4. Differentiating HCV Infection Stages by the Stimulation Index (SI) Parameter. The ability of the SMARTube HIV \& $\mathrm{HCV}$ to drive forward HCV antibody production, in a whole blood sample, is dependent on the presence of lymphocytes, primed in vivo by hepatitis $\mathrm{C}$ virus's antigens. $\mathrm{HCV}$-primed
$B$ cells (and T cells) would be present in the blood within days of infection, and newly produced naive $B$ cells will be primed by viral antigens for as long as the viral infection will persist [127]. Once the infection is cleared (spontaneously, or following ARV treatment), there will be no further priming of naive B cells (or T cells). At that time, while the already produced antibody levels in the blood will remain high for several years, the ability to enhance further antibody production, in vitro, by newly primed B cells would be gone within days. This hypothesis leads to additional analysis of the studies' results. In order to give a quantitative expression of the described processes, the ratio between the antibody levels in the SMARTplasma and the antibody levels in the plasma - the Stimulation Index (SI) - was calculated for each individual.

According to the obtained clinical laboratory results analyzed with SI, allocation can be made for four different possible intervals of values for this parameter. Moreover, each interval of SI values could serve as an indicator of a different stage in the HCV infection disease course.

Comparative analysis of $\mathrm{HCV}$ antibodies concentrations in SMARTplasma and plasma which were missed by regular serology, but detected after Stimmunology processing, shows very high "ratios" between antibody levels before and after Stimmunology blood pretreatment. Shortly after infection and prior to seroconversion, the antibody levels in the SMARTplasma would be much higher than in the plasma (which is actually negative, i.e., no (zero) OD due to specific antibodies), and thus the Stimulation Index is infinitesimal, that is, $\mathrm{SI}=\infty$ would indicate very early infection, or in other words, the seronegative window period.

Shortly after seroconversion there would be many HCVprimed B cells which have not yet matured to plasma cells. In our study, SI > 1.2 was considered to probably indicate recent seroconversion due to the fact that antibody production in vivo has not yet reached its full capacity.

During the chronic infection, the difference between the antibody levels in the SMARTplasma and in the plasma is insignificant. This is the reason why an SI value around 1.0 $(0.8<\mathrm{SI}<1.2)$ indicates a long-term infection.

The decline of SMARTplasma antibody levels, which happens shortly after the clearance of the HCV infection, can 
be explained by the fact that the level of antibodies in the SMARTplasma is dependent on both the antibodies already present in the blood and the newly produced antibodies, in culture, by HCV-primed B cells. With the primed cells gone from the blood shortly after the clearance of the virus from the body, the in vitro production will be gone too. Thus, the decrease of antibody levels in the SMARTplasma will precede the one observed in the plasma, and an SI index in interval SI $<0.8$ indicates a cleared infection.

The data of the HCV positives from the different clinical studies was analyzed for its SI values, and the results are presented in Table 4. In the blood samples tested in Russia, which were positive for HCV (total 13 samples), all the infections seem to be in the chronic phase. No recent infections and no infections in the window period were found. With such a small sample set it is statistically expected that the more rare situations (e.g., recent infection) will not be found. The same is true for the WP samples-of which none were detected.

In Hungary and Kenya there were $\sim 12 \%$ who cleared the infection, according to SI calculation. While no samples were from recently seroconverted individuals, there was one sample from a person in the WP in each country. In contrast, in Romania, Turkey, and China, more than one sample were detected in WP or with recent $\mathrm{HCV}$ infection $(5,3$, and 11, resp.), indicating a high incidence level in the studied populations. In epidemiological terms we can see how the SI could serve as a tool for incidences estimation. While in Romania and Turkey there were rather high ( 30\%) levels of cleared infections, there were none among the Chinese samples. The majority of the HCV-positive patients, in all studied populations, had a chronic infection.

The presented data shows that SI calculation may be used as a tool for differentiating between different stages of the HCV infection. The SI information could enable the distinction of those who recently seroconverted form carriers of long-term infection. This parameter can lead to identification of a person infected with viral hepatitis, early in the course of the disease and treat acute HCV with the new therapeutic resources. In addition, the SI can indicate cases of cleared infection and patients who do not need treatment or their treatment has been effective.

\section{Conclusions}

Identification of all HCV-infected individuals in high risk populations is important for early treatment, both for the sake of the patient and for society. Detection of all HCV infections among blood/organ donors could reduce the risk of HCV transmission caused by transfusion, transplantation, and dialysis. Using the innovative technology-Stimmunology, and its device, the SMARTube HIV \& HCV, as a preanalytical step prior to testing for HCV antibodies-enables the detection of additional infected carriers - those who are in the window period. Detection of these routine seronegative yet infected individuals is impossible by the currently available assays. In addition, SMARTube pretreatment improves specificity of HCV diagnostic assays and allows reduction of false positive results. Thus, the SMARTube could be applicable for changing the way we treat both the infected individual and the epidemic as a whole.

\author{
Abbreviations \\ HCV: HepatitisCvirus \\ WHO: WorldHealthOrganization \\ ST: $\quad$ Stimmunology \\ SI: $\quad$ StimulationIndex \\ WP: Windowperiod \\ ELISA: Enzyme-linkedimmunosorbentassay \\ OD: Opticaldensity \\ IDU: Intravenousdrugusers.
}

\section{Conflict of Interests}

All studies were conducted and analyzed by independent researchers: S. Unal; Y. Wang; M. I. Mikhaylov; L. Bigbulatova. They are all with no interests with, or at, the manufacturing company SMART Biotech. The data from all the different sites was compiled by S. Gorodin and analyzed by her and T. Jehuda-Cohen; they both are employees of the company, and T. Jehuda-Cohen also has shares in it.

\section{Acknowledgment}

Professor Jaspar Mumo, from the University of Nairobi, Kenya, designed and conducted the studies in Kenya and has done the scientific analysis of the data. He has passed away prior to the submission of this paper.

\section{References}

[1] S. L. Chen and T. R. Morgan, "The natural history of hepatitis $\mathrm{C}$ virus (HCV) infection," International Journal of Medical Sciences, vol. 3, no. 2, pp. 47-52, 2006.

[2] WHO, World Health Organization. Hepatitis C Fact sheet $N^{\circ} 164$, http://www.who.int/mediacentre/factsheets/fs164/en/, 2011.

[3] WHO, World Health Organization. Hepatitis C Fact Sheet, http://www.who.int/mediacentre/factsheets/fs164/en/, 2007.

[4] WHO, World Health Organization. Hepatitis C, http://www .who.int/vaccine_research/diseases/viral_cancers/en/index2 .html, 2007.

[5] E. Chak, A. H. Talal, K. E. Sherman, E. R. Schiff, and S. Saab, "Hepatitis C virus infection in USA: an estimate of true prevalence," Liver International, vol. 31, no. 8, pp. 1090-1101, 2011.

[6] S. V. Netesov, "Problems of developing hepatitis C and HIV vaccines," Herald of the Russian Academy of Sciences, vol. 78, no. 5, pp. 443-456, 2008.

[7] C. Trépo and P. Pradat, "Hepatitis C virus infection in Western Europe," Journal of Hepatology, vol. 31, supplement 1, pp. 80-83, 1999.

[8] S. Deuffic-Burban, M. K. Mohamed, B. Larouze, F. Carrat, and A. J. Valleron, "Expected increase in hepatitis C-related mortality in Egypt due to pre-2000 infections," Journal of Hepatology, vol. 44, no. 3, pp. 455-461, 2006.

[9] S. Eassa, M. Eissa, S. M. Sharaf, M. H. Ibrahim, and O. M. Hassanein, "Prevalence of hepatitis $\mathrm{C}$ virus infection and evaluation of a health education program in el-ghar village in zagazig, 
egypt," Journal of the Egyptian Public Health Association, vol. 82, no. 5-6, pp. 379-404, 2007.

[10] Y. Wang, Q. M. Tao, H. Y. Zhao et al., "Hepatitis C virus RNA and antibodies among blood donors in Beijing," Journal of Hepatology, vol. 21, no. 4, pp. 634-640, 1994.

[11] T. Sy and M. M. Jamal, "Epidemiology of hepatitis C virus (HCV) infection," International Journal of Medical Sciences, vol. 3, no. 2, pp. 41-46, 2006.

[12] B. E. O. Sarkari, A. Khosravani, A. Sharifi, M. Tabatabaee, and M. Fararouei, "High prevalence of hepatitis C infection among high risk groups in Kohgiloyeh and Boyerahmad province, Southwest Iran," Archives of Iranian medicine, vol. 15, no. 5, pp. 271-274, 2012.

[13] E. Diro, S. Alemu, and A. Yohannes, "Blood safety \& prevalence of transfussion transmissible viral infections among donors at the Red Cross Blood Bank in Gondar University Hospital," Ethiopian Medical Journal, vol. 46, no. 1, pp. 7-13, 2008.

[14] Z. A. Jeremiah, B. Koate, F. Buseri, and F. Emelike, "Prevalence of antibodies to hepatitis $\mathrm{C}$ virus in apparently healthy Port Harcourt blood donors and association with blood groups and other risk indicators," Blood Transfusion, vol. 6, no. 3, pp. 150155, 2008.

[15] A. Soza, M. Arrese, R. González et al., "Clinical and epidemiological features of 147 Chilean patients with chronic hepatitis C," Annals of Hepatology, vol. 3, no. 4, pp. 146-151, 2004.

[16] E. Kupek, "Transfusion risk for hepatitis B, hepatitis C and HIV in the state of Santa Catarina, Brazil, 1991-2001," The Brazilian Journal of Infectious Diseases, vol. 8, no. 3, pp. 236-240, 2004.

[17] H. Q. Zhang, S. B. Li, G. H. Wang, K. Chen, X. G. Song, and X. Y. Feng, "Detection of hepatitis $\mathrm{C}$ virus core antigen for early diagnosis of hepatitis $\mathrm{C}$ virus infection in plasma donor in China," World Journal of Gastroenterology, vol. 13, no. 19, pp. 2738-2742, 2007.

[18] G. A. Schmunis and J. R. Cruz, "Safety of the blood supply in Latin America," Clinical Microbiology Reviews, vol. 18, no. 1, pp. 12-29, 2005.

[19] İ. Dilek, C. Demir, A. Bay, H. Akdeniz, and A. F. Öner, "Seropositivity rates of HBsAg, anti-HCV, anti-HIV and VDRL in blood donors in Eastern Turkey," Turkish Journal of Hematology, vol. 24, no. 1, pp. 4-7, 2007.

[20] L. Zhang, Z. Chen, Y. Cao et al., "Molecular characterization of human immunodeficiency virus type 1 and hepatitis $C$ virus in paid blood donors and injection drug users in China," Journal of Virology, vol. 78, no. 24, pp. 13591-13599, 2004.

[21] P. Bourgois, B. Prince, and A. Moss, "The everyday violence of hepatitis C among young women who inject drugs in San Francisco," Human Organization, vol. 63, no. 3, pp. 253-264, 2004.

[22] X. Xia, J. Luo, J. Bai, and R. Yu, "Epidemiology of hepatitis C virus infection among injection drug users in China: systematic review and meta-analysis," Public Health, vol. 122, no. 10, pp. 990-1003, 2008.

[23] G. Shimokura, F. Chai, D. J. Weber et al., "Patient-care practices associated with an increased prevalence of hepatitis $\mathrm{c}$ virus infection among chronic hemodialysis patients," Infection Control and Hospital Epidemiology, vol. 32, no. 5, pp. 415-424, 2011.

[24] M. A. M. Santos and F. J. D. Souto, "Infection by the hepatitis C virus in chronic renal failure patients undergoing hemodialysis in Mato Grosso state, central Brazil: a cohort study," BMC Public Health, vol. 7, p. 32, 2007.
[25] A. A. Shamshirsaz, M. Kamgar, M. R. Bekheirnia et al., "The role of hemodialysis machines dedication in reducing Hepatitis $\mathrm{C}$ transmission in the dialysis setting in Iran: a multicenter prospective interventional study," BMC Nephrology, vol. 5, no. 13, pp. 1-5, 2004.

[26] D. K. Henderson, "Managing occupational risks for hepatitis C transmission in the health care setting," Clinical Microbiology Reviews, vol. 16, no. 3, pp. 546-568, 2003.

[27] R. C. Moreira, M. F. Lemos, C. A. Longui, and C. Granato, "Hepatitis C and hemodialysis: a review," Brazilian Journal of Infectious Diseases, vol. 9, no. 4, pp. 269-275, 2005.

[28] D. Kershenobich, "Treatment of HCV infected patients and renal disease," Annals of Hepatology, vol. 9, no. 1, pp. 103-106, 2010.

[29] S. K. Agarwal, "Hemodialysis of patients with HCV infection: isolation has a definite role," Nephron-Clinical Practice, vol. 117, no. 4, pp. c328-c332, 2011.

[30] S. Khan, S. Attaullah, S. Ayaz et al., "Molecular epidemiology of HCV among health care workers of Khyber Pakhtunkhwa," Virology Journal, vol. 8, p. 105, 2011.

[31] A. Marconi, S. Candido, R. Talamini et al., "Prevalence of hepatitis $\mathrm{C}$ virus infection among health-care workers: a 10-year survey," Molecular Medicine Reports, vol. 3, no. 4, pp. 561-564, 2010.

[32] S. Deuffic-Burban, E. Delarocque-Astagneau, D. Abiteboul, E. Bouvet, and Y. Yazdanpanah, "Blood-borne viruses in health care workers: prevention and management," Journal of Clinical Virology, vol. 52, no. 1, pp. 4-10, 2011.

[33] J. Birguel, J. G. Ndong, S. Akhavan et al., "[Viral markers of hepatitis $B, C$ and $D$ and $H B$ vaccination status of a health care team in a rural district of Cameroon]," Médecine Tropicale, vol. 71, no. 2, pp. 201-202, 2011.

[34] S. Hosoglu, S. Akalin, M. Sunbul, M. Otkun, and R. Ozturk, "Healthcare workers' compliance with universal precautions in Turkey," Medical Hypotheses, vol. 77, no. 6, pp. 1079-1082, 2011.

[35] CDC, Sexually Transmitted Diseases Treatment Guidelines, http://www.cdc.gov/std/treatment/2010/, 2010.

[36] S. Dougan, M. A. Balogun, J. Elford et al., "Can current national surveillance systems in England and Wales monitor sexual transmission of hepatitis C among HIV-infected men who have sex with men?" BMC Public Health, vol. 7, p. 7, 2007.

[37] M. Plamondon, A. C. Labbé, E. Frost et al., "Hepatitis C virus infection in Guinea-Bissau: a sexually transmitted genotype 2 with parenteral amplification?" PLoS ONE, vol. 2, no. 4, p. e372, 2007.

[38] J. T. Blackard, M. T. Shata, N. J. Shire, and K. E. Sherman, "Acute hepatitis C virus infection: a chronic problem," Hepatology, vol. 47, no. 1, pp. 321-331, 2008.

[39] R. Browne, D. Asboe, Y. Gilleece et al., "Increased numbers of acute hepatitis $\mathrm{C}$ infections in HIV positive homosexual men; is sexual transmission feeding the increase? [4]," Sexually Transmitted Infections, vol. 80, no. 4, pp. 326-327, 2004.

[40] H. M. Lekas, K. Siegel, and J. Leider, "Challenges facing providers caring for $\mathrm{HIV} / \mathrm{HCV}$-coinfected patients," Qualitative Health Research, vol. 22, no. 1, pp. 54-66, 2012.

[41] V. Baldo, T. Baldovin, R. Trivello, and A. Floreani, "Epidemiology of HCV infection," Current Pharmaceutical Design, vol. 14, no. 17, pp. 1646-1654, 2008.

[42] J. Ward, F. Averhoff, and H. Koh, "World Hepatitis Day: a new era for hepatitis control," The Lancet, vol. 378, no. 9791, pp. 552$553,2011$. 
[43] P. Kar, "World Hepatitis Day—new challenges," Indian Journal of Medical Research, vol. 134, pp. 1-3, 2012.

[44] T. Burki, "World Hepatitis Day to tackle viral hepatitis," Lancet Infectious Diseases, vol. 11, no. 8, pp. 589-590, 2011.

[45] D. P. Kolk, J. Dockter, J. Linnen et al., "Significant closure of the human immunodeficiency virus type 1 and hepatitis $C$ virus preseroconversion detection windows with a transcriptionmediated-amplification-driven assay," Journal of Clinical Microbiology, vol. 40, no. 5, pp. 1761-1766, 2002.

[46] J. F. Cantaloube, P. Gallian, H. Attoui, P. Biagini, P. De Micco, and X. De Lamballerie, "Genotype distribution and molecular epidemiology of hepatitis $\mathrm{C}$ virus in blood donors from Southeast France," Journal of Clinical Microbiology, vol. 43, no. 8, pp. 3624-3629, 2005.

[47] C. Hézode, "Boceprevir and telaprevir for the treatment of chronic hepatitis C: safety management in clinical practice," Liver International, vol. 32, supplement 1, pp. 32-38, 2012.

[48] FDA, "Two Protease Inhibitors for HCV. Victrelis, Incivek," PMC, Pharmacy and Therapeutics, New Drugs, vol. 36, no. 6, pp. 320-331, 2011.

[49] J. Vermehren and C. Sarrazin, "New hepatitis C therapies in clinical development," European Journal of Medical Research, vol. 16, no. 7, pp. 303-314, 2011.

[50] S. J. Aronson, J. de Bruijne, J. Schinkel, C. J. Weegink, M. van der Valk, and H. W. Reesink, "New class of medicines for chronic hepatitis C," Nederlands Tijdschrift voor Geneeskunde, vol. 156, no. 10, p. A3840, 2012 (Dutch).

[51] B. Adiwijaya, T. L. Kieffer, J. Henshaw et al., "A viral dynamic model for treatment regimens with direct-acting antivirals for chronic hepatitis c infection," PLOS Computational Biology, vol. 8, no. 1, p. e1002339, 2012.

[52] J. Vermehren and C. Sarrazin, "New hepatitis C therapies in clinical development," European Journal of Medical Research, vol. 16, no. 7, pp. 303-314, 2011.

[53] J. Ward, "Identification, screening, and surveillance in era of improving therapy for hepatitis C symposium," in Identification, Screening and Surveillance of HCV Infections in the Era of Improved Therapy For Hepatitis C, CDC's Roybal Campus, Atlanta, Ga, USA, 2011.

[54] A. S. F. Lok and N. T. Gunaratnam, "Diagnosis of hepatitis C, Hepatology, vol. 26, no. 3, 1997.

[55] K. A. Musana, S. H. Yale, and A. S. Abdulkarim, "Tests of liver injury," Clinical Medicine \& Research, vol. 2, no. 2, pp. 129-131, 2004.

[56] G. Icardi, F. Ansaldi, B. M. Bruzzone et al., "Novel approach to reduce the hepatitis $\mathrm{C}$ virus $(\mathrm{HCV})$ window period: clinical evaluation of a new enzyme-linked immunosorbent assay for HCV core antigen," Journal of Clinical Microbiology, vol. 39, no. 9, pp. 3110-3114, 2001.

[57] S. Chevaliez and J. M. Pawlotsky, "Hepatitis C virus serologic and virologic tests and clinical diagnosis of HCV-related liver disease," International Journal of Medical Sciences, vol. 3, no. 2, pp. 35-40, 2006.

[58] B. C. Dow, H. Munro, I. Buchanan et al., "Acute hepatitis C virus seroconversion in a Scottish blood donor: HCV antigen is not comparable with HCV nucleic acid amplification technology screening," Vox Sanguinis, vol. 86, no. 1, pp. 15-20, 2004.

[59] H. Mine, H. Emura, M. Miyamoto et al., "High throughput screening of 16 million serologically negative blood donors for hepatitis $\mathrm{B}$ virus, hepatitis $\mathrm{C}$ virus and human immunodeficiency virus type-1 by nucleic acid amplification testing with specific and sensitive multiplex reagent in Japan," Journal of Virological Methods, vol. 112, no. 1-2, pp. 145-151, 2003.

[60] L. M. Jarvis, B. C. Dow, A. Cleland et al., "Detection of HCV and HIV-1 antibody negative infections in Scottish and Northern Ireland blood donations by nucleic acid amplification testing," Vox Sanguinis, vol. 89, no. 3, pp. 128-134, 2005.

[61] D. Forčić, R. Zgorelec, K. Branović, T. Košutić-Gulija, M. Šantak, and R. Mažuran, "Incidence of hepatitis C virus RNA in anti-HCV negative plasma pools in Croatia," Transfusion and Apheresis Science, vol. 24, no. 3, pp. 269-278, 2001.

[62] S. A. Galel, D. M. Strong, G. E. Tegtmeier et al., "Comparative yield of HCV RNA testing in blood donors screened by 2.0 versus 3.0 antibody assays," Transfusion, vol. 42, no. 11, pp. 15071513, 2002.

[63] C. A. Hyland, C. R. Seed, P. Kiely, S. Parker, N. Cowley, and W. Bolton, "Follow-up of six blood donors highlights the complementary role and limitations of hepatitis $C$ virus antibody and nucleic acid amplification tests," Vox Sanguinis, vol. 85, no. 1, pp. 1-8, 2003.

[64] S. Medhi, S. K. Potukuchi, S. K. Polipalli et al., "Diagnostic utility of hepatitis C virus core antigen in hemodialysis patients," Clinical Biochemistry, vol. 41, no. 447, p. 452, 2008.

[65] C. T. Fang, S. P. Field, M. P. Busch, and A. D. P. Heyns, "Human immunodeficiency virus-1 and hepatitis $C$ virus RNA among South African blood donors: estimation of residual transfusion risk and yield of nucleic acid testing," Vox Sanguinis, vol. 85, no. 1, pp. 9-19, 2003.

[66] C. L. van der Poel, H. T. Cuypers, and H. W. Reesink, "Hepatitis C virus six years," The Lancet, vol. 344, no. 8935, pp. 1475-1479, 1994.

[67] H. Chiba, T. Takezaki, D. Neupani et al., "An epidemiological study of HBV, HCV and HTLV-I in Sherpas of Nepal," Asian Pacific Journal of Cancer Prevention, vol. 5, no. 4, pp. 370-373, 2004.

[68] C. M. Chu, C. T. Yeh, I. S. Sheen, and Y. F. Liaw, "Acute hepatitis $\mathrm{C}$ virus (HCV) infection in chronic carriers of hepatitis B virus (HBV): the impact of underlying active HBV replication on persistence of HCV infection and antibody responses to HCV," Gut, vol. 51, no. 1, pp. 95-99, 2002.

[69] J. P. Allain, "Genomic screening for blood-borne viruses in transfusion settings," Clinical and Laboratory Haematology, vol. 22, no. 1, pp. 1-10, 2000.

[70] M. P. Busch and S. H. Kleinman, "Nucleic acid amplification testing of blood donors for transfusion- transmitted infectious diseases," Transfusion, vol. 40, no. 2, pp. 143-159, 2000.

[71] J. L. Gallarda, "Blood screening by nucleic acid amplification technology: current issues, future challenges," Molecular Diagnosis, vol. 5, no. 1, pp. 11-22, 2000.

[72] E. L. Delwart, N. D. Kalmin, T. S. Jones et al., "First report of human immunodeficiency virus transmission via an RNAscreened blood donation," Vox Sanguinis, vol. 86, no. 3, pp. 171177, 2004.

[73] J. J. Weusten, H. A. van Drimmelen, and P. N. Lelie, "Mathematic modeling of the risk of $\mathrm{HBV}, \mathrm{HCV}$, and HIV transmission by window-phase donations not detected by NAT,' Transfusion, vol. 42, no. 5, pp. 537-548, 2002.

[74] W. E. Hitzler and S. Runkel, "Routine HCV PCR screening of blood donations to identify early HCV infection in blood donors lacking antibodies to HCV,' Transfusion, vol. 41, no. 3, pp. 333-337, 2001. 
[75] W. K. Roth, M. Weber, S. Buhr et al., "Yield of HCV and HIV-1 NAT after screening of 3.6 million blood donations in central Europe," Transfusion, vol. 42, no. 7, pp. 862-868, 2002.

[76] M. S. Bamaga, F. F. Bokhari, A. M. Aboud, M. Al-Malki, and F. Q. Alenzi, "Nucleic acid amplification technology screening for hepatitis $\mathrm{C}$ virus and human immunodeficiency virus for blood donations," Saudi Medical Journal, vol. 27, no. 6, pp. 781787, 2006

[77] E. Kretzschmar, M. Chudy, C. M. Nübling, R. S. Ross, F. Kruse, and $\mathrm{H}$. Trobisch, "First case of hepatitis $\mathrm{C}$ virus transmission by a red blood cell concentrate after introduction of nucleic acid amplification technique screening in Germany: a comparative study with various assays," Vox Sanguinis, vol. 92, no. 4, pp. 297301, 2007.

[78] A. E. Ling, T. M. Brown, V. Dunmire et al., "Failure of routine HIV-1 tests in a case involving transmission with preseroconversion blood components, during the infectious window period," Journal of the American Medical Association, vol. 284, no. 2, pp. 210-214, 2000.

[79] D. Gray, Four Transplant Recipients Contract H.I.V, The New York Times, New York, NY, USA, 2007.

[80] M. Marvin, M. Steele, S. K. Green et al., "Transmission of hepatitis C virus through transplanted organs and tissueKentucky and Massachusetts, 2011. Centers for Disease Control and Prevention (CDC)," MMWR Morbidity and Mortality Weekly Report, vol. 3, pp. 61-80, 2012.

[81] A. L. Singer, L. M. Kucirka, R. Namuyinga, C. Hanrahan, A. K. Subramanian, and D. L. Segev, "The high-risk donor: viral infections in solid organ transplantation," Current Opinion in Organ Transplantation, vol. 13, no. 4, pp. 400-404, 2008.

[82] M. P. Busch, L. L. L. Lee, G. A. Satten et al., "Time course of detection of viral and serologic markers preceding human immunodeficiency virus type 1 seroconversion: implications for screening of blood and tissue donors," Transfusion, vol. 35, no. 2, pp. 91-97, 1995.

[83] A. M. Contreras, C. M. Tornero-Romo, J. G. Toribio et al., "Very low hepatitis $\mathrm{C}$ antibody levels predict false-positive results and avoid supplemental testing," Transfusion, vol. 48, no. 12, pp. 2540-2548, 2008.

[84] J. M. Watterson, P. Stallcup, D. Escamilla, P. Chernay, A. Reyes, and S. C. Trevino, "Evaluation of the ortho-clinical diagnostics vitros ECi Anti-HCV test: comparison with three other methods," Journal of Clinical Laboratory Analysis, vol. 21, no. 3, pp. 162-166, 2007.

[85] M. Kita, M. Deguchi, M. Kagita et al., "Clinical utility and characteristics of nine anti-HCV antibody screening reagents used in Japan," Clinical Laboratory, vol. 55, no. 1-2, pp. 9-22, 2009.

[86] S. Amuduwage, S. Weerasingam, S. Jayasinghe, and N. Fernandopulle, "Hepatitis $\mathrm{C}$ virus in healthy blood donors in Sri Lanka," Asian Journal of Transfusion Science, vol. 5, no. 1, pp. 23-25, 2011.

[87] A. Ali and A. Lal, "False positivity of serological tests for hepatitis C virus," Journal of Ayub Medical College, Abbottabad, vol. 22, no. 2, pp. 43-45, 2010.

[88] P. Vermeersch, M. Van Ranst, and K. Lagrou, "Evaluation of the use of a combined HCV antigen/antibody assay in routine laboratory practice," Acta Clinica Belgica, vol. 65, no. 4, pp. 245247, 2010.

[89] S. V. Fedorchenko, T. L. Martynovich, O. V. Lyashok, Z. A. Karyuk, and V. I. Yanchenko, "Spontaneous HCV clearance: an association with gender, age, viral genotypes, infection transmission routes, and markers of HBV and HIV," Terapevticheskii Arkhiv, vol. 82, no. 3, pp. 52-56, 2010.

[90] J. M. Watterson, P. Stallcup, D. Escamilla, P. Chernay, A. Reyes, and S. C. Trevino, "Evaluation of the ortho-clinical diagnostics vitros ECi Anti-HCV test: comparison with three other methods," Journal of Clinical Laboratory Analysis, vol. 21, no. 3, pp. 162-166, 2007.

[91] J. T. Gerlach, H. M. Diepolder, R. Zachoval et al., "Acute hepatitis $\mathrm{C}$ : high rate of both spontaneous and treatmentinduced viral clearance," Gastroenterology, vol. 125, no. 1, pp. 8088, 2003.

[92] T. Santantonio, M. Fasano, E. Sinisi et al., "Efficacy of a 24-week course of PEG-interferon $\alpha$-2b monotherapy in patients with acute hepatitis C after failure of spontaneous clearance," Journal of Hepatology, vol. 42, no. 3, pp. 329-333, 2005.

[93] A. L. Cox, D. M. Netski, T. Mosbruger et al., "Prospective evaluation of community-acquired acute-phase hepatitis C virus infection," Clinical Infectious Diseases, vol. 40, no. 7, pp. 951-958, 2005.

[94] A. Larghi, M. Zuin, A. Crosignani et al., "Outcome of an outbreak of acute hepatitis $\mathrm{C}$ among healthy volunteers participating in pharmacokinetics studies," Hepatology, vol. 36, no. 4, pp. 993-1000, 2002.

[95] M. Jauncey, J. M. Micallef, S. Gilmour et al., "Clearance of hepatitis $\mathrm{C}$ virus after newly acquired infection in injection drug users," Journal of Infectious Diseases, vol. 190, no. 7, pp. 12701274, 2004.

[96] A. Takaki, M. Wiese, G. Maertens et al., "Cellular immune responses persist and humoral responses decrease two decades after recovery from a single-source outbreak of hepatitis C," Nature Medicine, vol. 6, no. 5, pp. 578-582, 2000.

[97] S. Keating, S. Coughlan, J. Connell, B. Sweeney, and E. Keenan, "Hepatitis $\mathrm{C}$ viral clearance in an intravenous drug-using cohort in the Dublin area," Irish Journal of Medical Science, vol. 174, no. 1, pp. 37-41, 2005.

[98] H. Y. Rao, D. G. Sun, D. Jiang et al., "IL28B genetic variants and gender are associated with spontaneous clearance of hepatitis $\mathrm{C}$ virus infection," Journal of Viral Hepatitis, 2011.

[99] A. S. Abdel-Moneim, M. S. Bamaga, G. M. Shehab, A. A. Abu-Elsaad, and F. M. Farahat, "HCV infection among Saudi population: high prevalence of genotype 4 and increased viral clearance rate," PLoS One, vol. 7, no. 1, p. e29781, 2012.

[100] C. Schlecker, A. Ultsch, G. Geisslinger, and J. Lotsch, "The pharmacogenetic background of hepatitis C treatment," Mutation Research, vol. 751, no. 1, pp. 36-48, 2012.

[101] G. Missale, M. Pilli, A. Zerbini et al., "Lack of full CD8 functional restoration after antiviral treatment for acute and chronic hepatitis C virus infection," Gut, vol. 61, no. 7, pp. 1076$1084,2012$.

[102] M. F. Meyer, M. Lehmann, M. Cornberg et al., "Clearance of low levels of HCV viremia in the absence of a strong adaptive immune response," Virology Journal, vol. 4, p. 58, 2007.

[103] J. Schulze Zur Wiesch, D. Ciuffreda, L. Lewis-Ximenez et al., "Broadly directed virus-specific CD4+ T cell responses are primed during acute hepatitis $\mathrm{C}$ infection, but rapidly disappear from human blood with viral persistence," Journal of Experimental Medicine, vol. 209, no. 1, pp. 61-75, 2012.

[104] B. Heyman, "Regulation of antibody responses via antibodies, complement, and Fc receptors," Annual Review of Immunology, vol. 18, pp. 709-737, 2000. 
[105] E. L. Delwart, N. D. Kalmin, T. S. Jones et al., "First report of human immunodeficiency virus transmission via an RNAscreened blood donation," Vox Sanguinis, vol. 86, no. 3, pp. 171177, 2004.

[106] E. Kretzschmar, M. Chudy, C. M. Nübling, R. S. Ross, F. Kruse, and $\mathrm{H}$. Trobisch, "First case of hepatitis $\mathrm{C}$ virus transmission by a red blood cell concentrate after introduction of nucleic acid amplification technique screening in Germany: a comparative study with various assays," Vox Sanguinis, vol. 92, no. 4, pp. 297301, 2007.

[107] T. Jehuda-Cohen, J. D. Powell, F. Villinger, A. E. Mayne, K. W. Sell, and A. A. Ansari, "Evidence for simian immunodeficiency virus-specific IgM and IgG response in peripheral blood mononuclear cells of serum enzyme-linked immunosorbent assay-negative nonhuman primates," Journal of Acquired Immune Deficiency Syndromes, vol. 7, no. 6, pp. 539-550, 1994.

[108] F. Villinger, J. D. Powell, T. Jehuda-Cohen et al., "Detection of occult simian immunodeficiency virus SIVsmm infection in asymptomatic seronegative nonhuman primates and evidence for variation in SIV gag sequence between in vivo- and in vitropropagated virus," Journal of Virology, vol. 65, no. 4, pp. 1855$1862,1991$.

[109] A. Olshansky, "Possibility of SMARTube application for optimization of hepatitis C and HIV- infections diagnosis," in Proceedings of the 8th International Conference, Viral Hepatitis: Problems of Epidemiology, Diagnostics, Treatment \& Prevention, Moscow, Russia, 2009.

[110] T. Jehuda-Cohen and I. Novikov, "HIV Type 1 infection among ethiopian immigrants to Israel: enhanced in vitro antibody stimulation for estimating the length of the window period," AIDS Research and Human Retroviruses, vol. 25, no. 2, pp. 165174, 2009.

[111] L. N. Bicbulatova, E. L. Vavilova, N. N. Ivashenko, and M. I. Mikhailov, "Diagnostic importance of the SMARTube test in detection of antibodies to HIV," in Proceedings of the International Conference of Development of Research and Supervision of Infectious Diseases, Pasteur Institute of Epidemiology and Microbiology, St. Petersburg, Russia, May 2010.

[112] J. Mumo, A. Vansover, and T. Jehuda-Cohen, "Detecting seronegative-early HIV infections among adult versus student Kenyan blood donors, by using stimmunology," Experimental Biology and Medicine, vol. 234, no. 8, pp. 931-939, 2009.

[113] T. Jehuda-Cohen, The HIV Seronegative Window Period: Diagnostic Challenges and Solutions. Recent Translational Research in HIV/AIDS/ Book 3, InTech Publishing House, Hampshire, UK, 2011.

[114] V. Bica, D. Stoenescu, L. Negrutiu et al., "Preliminary data concerning primary detection of HCV infection using SMARTube," in Proceedings of the National Infectious Diseases Conference, Timisora, Romania, 2007.

[115] E. Ujhelyi, "Serological catches of Hepatitis. New possibilities in the detection of Hepatitis C," in Proceedings of the Blood Banks'Conference 'The role of Quality Assurance and Control in Transfusiology', Budapest, Hungary, 2010.

[116] T. Jehuda-Cohen and S. Gorodin, "Overcoming, in-vitro, the specific immune suppression during the window period of HCV infection enables the detection of currently missed infected individuals," in Proceedings of the 13th International Symposium on Viral Hepatitis and Liver Disease, Washington, DC, USA, 2009.

[117] Culture tubes for the Stimmunology process. SMART BIOTECH LTD. 2 Bergman St. Rabin Science Park, Rehovot 76705, Israel.
[118] F. Liu, K. Chen, Z. He et al., "Hepatitis C seroprevalence and associated risk factors, Anyang, China," Emerging Infectious Diseases, vol. 15, no. 11, pp. 1819-1822, 2009.

[119] K. Dente and J. Hess, "Pediatric AIDS in Romania-a country faces its epidemic and serves as a model success," MedGenMed Medscape General Medicine, vol. 8, no. 2, p. 11, 2006.

[120] Y. C. Hutin, I. N. Nedelcu, E. E. Mast, M. J. Alter, and H. S. Margolis, "Using surveillance data to monitor key aspects of the epidemiology of hepatitis B virus (HBV) infection in Romania," in Proceedings of the 36th Annual Meeting of the Infectious Disease Society of America, Denver, Colo, USA, November 1998, Poster 36.

[121] C. A. Kozinetz, R. Matusa, and A. Cazacu, "The burden of pediatric HIV/AIDS in Constanta, Romania: a cross-sectional study," BMC Infectious Diseases, vol. 1, p. 7, 2001.

[122] S. M. Ruta, R. F. Matusa, C. Sultana et al., "High prevalence of hepatitis B virus markers in Romanian adolescents with human immunodeficiency virus infection," MedGenMed Medscape General Medicine, vol. 7, no. 1, p. 68, 2005.

[123] C. Boboş, I. Spânu, and A. Bîlc, "Antibodies against HBV, HCV and HAV detected by using microparticle enzyme immunoassay in hepatitis outpatients," Roumanian Archives of Microbiology and Immunology, vol. 65, no. 3-4, pp. 87-92, 2006.

[124] X. Gao, Q. Cui, X. Shi et al., "Prevalence and trend of hepatitis $\mathrm{C}$ virus infection among blood donors in Chinese mainland: a systematic review and meta-analysis," BMC Infectious Diseases, vol. 11, p. 88, 2011.

[125] "The HIV seronegative Window period: diagnostic challenges and solutions," in Recent Translational Research in HIV/AIDS, T. Jehuda-Cohen, Ed., pp. 179-202, InTech, Hampshire, UK, 2011.

[126] "The concept of donation of blood and blood components in the Russian Federation up to 2010," Transfusiology, vol. 1, pp. 61-67, 2003 (Russian).

[127] A. Y. Kim, J. S. Zur Wiesch, T. Kuntzen et al., "Impaired hepatitis $\mathrm{C}$ virus-specific $\mathrm{T}$ cell responses and recurrent hepatitis $\mathrm{C}$ virus in HIV coinfection," PLoS Medicine, vol. 3, no. 12, pp. 23242334, 2006. 

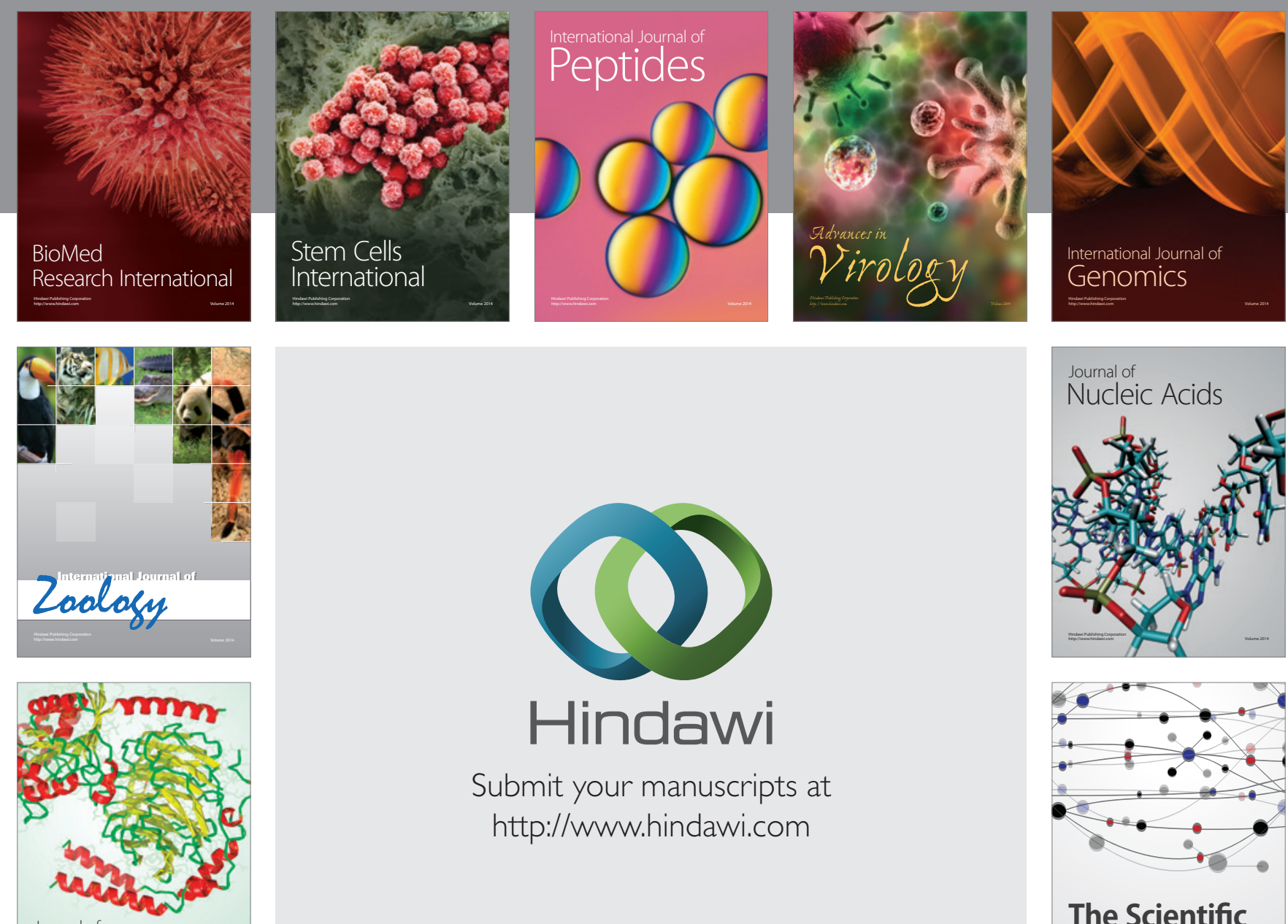

Submit your manuscripts at

http://www.hindawi.com

Journal of
Signal Transduction
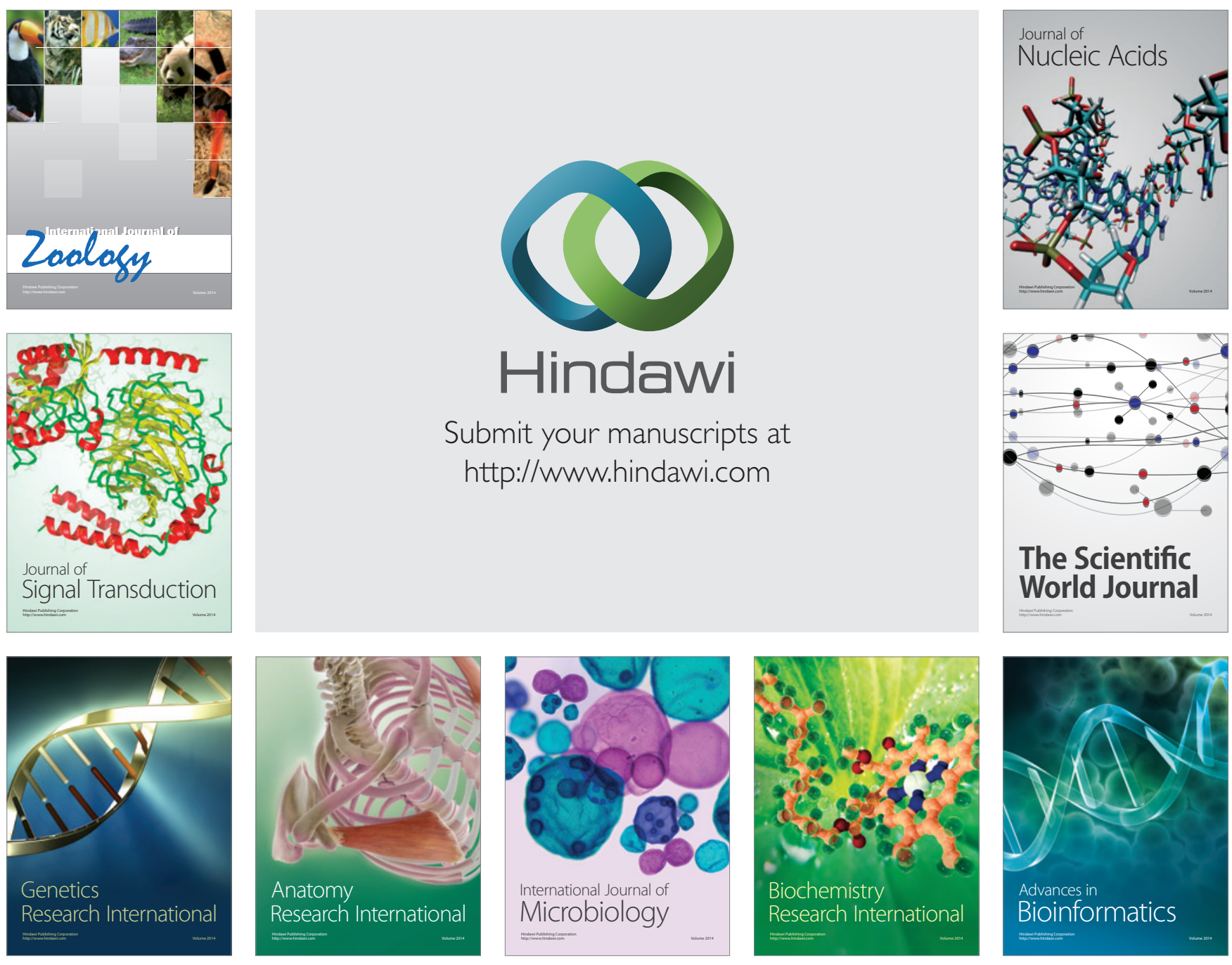

The Scientific World Journal
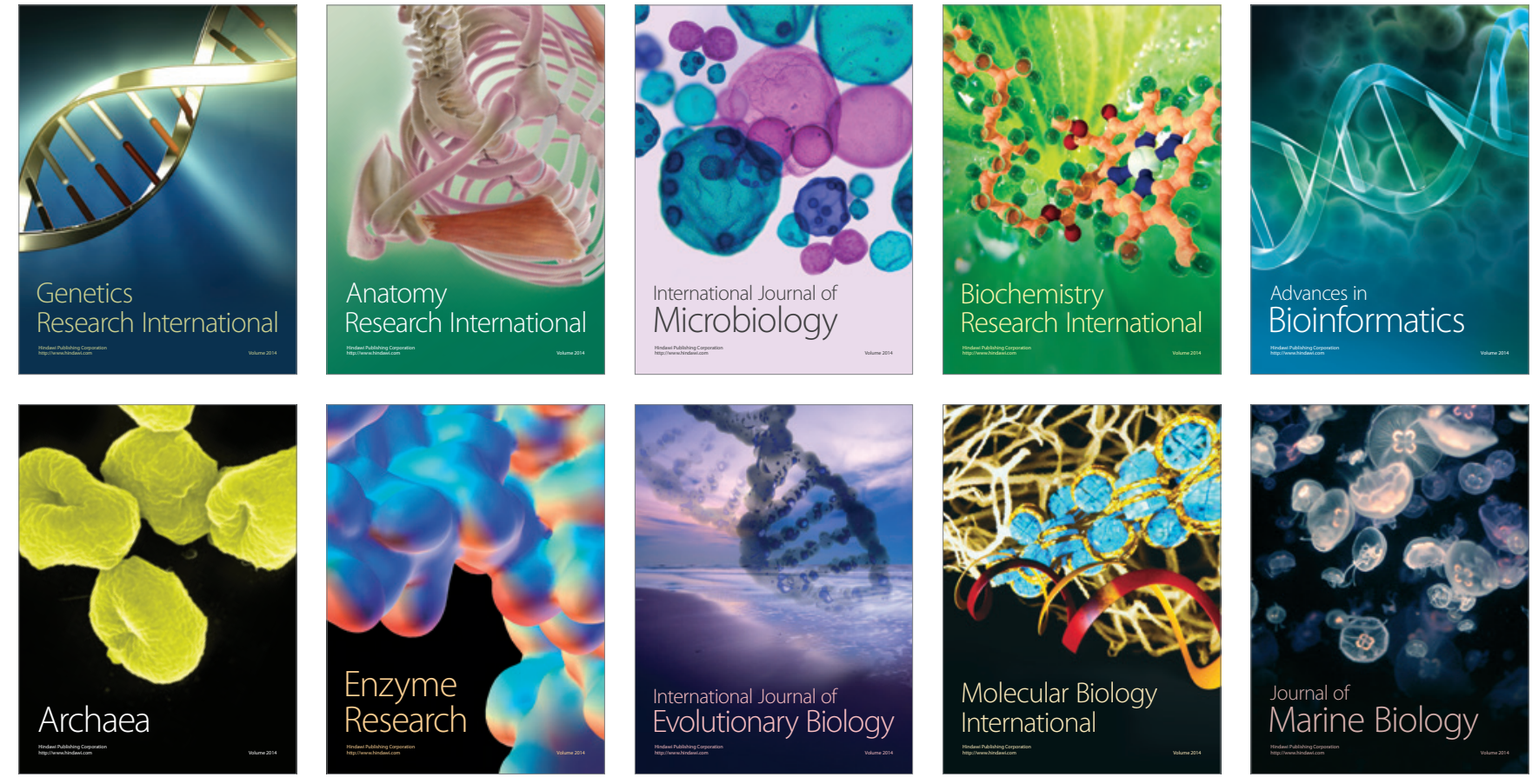